\title{
Molecular detection and phylogenetic analysis of lumpy skin disease virus from outbreaks in Uganda 2017-2018
}

Sylvester Ochwo ${ }^{1}$, Kimberly VanderWaal ${ }^{2}$, Christian Ndekezi ${ }^{1}$, Joseph Nkamwesiga' ${ }^{1}$, Anna Munsey², Sarah Gift Witto ${ }^{1}$, Noelina Nantima ${ }^{3}$, Franklin Mayanja ${ }^{3}$, Anna Rose Ademun Okurut ${ }^{3}$, David Kalenzi Atuhaire ${ }^{1}$ and Frank Norbert Mwiine ${ }^{1 *}$ (D)

\begin{abstract}
Background: Lumpy skin disease (LSD) is an infectious viral disease of cattle caused by a Capripoxvirus. LSD has substantial economic implications, with infection resulting in permanent damage to the skin of affected animals which lowers their commercial value. In Uganda, LSD is endemic and cases of the disease are frequently reported to government authorities. This study was undertaken to molecularly characterize lumpy skin disease virus (LSDV) strains that have been circulating in Uganda between 2017 and 2018. Secondly, the study aimed to determine the phylogenetic relatedness of Ugandan LSDV sequences with published sequences, available in GenBank.

Results: A total of 7 blood samples and 16 skin nodule biopsies were screened for LSDV using PCR to confirm presence of LSDV nucleic acids. PCR positive samples were then characterised by amplifying the GPCR gene. These amplified genes were sequenced and phylogenetic trees were constructed. Out of the 23 samples analysed, 15 were positive for LSDV by PCR (65.2\%). The LSDV GPCR sequences analysed contained the unique signatures of LSDV (A11, T12, T34, S99, and P199) which further confirmed their identity. Sequence comparison with vaccine strains revealed a 12 bp deletion unique to Ugandan outbreak strains. Phylogenetic analysis indicated that the LSDV sequences from this study clustered closely with sequences from neighboring East African countries and with LSDV strains from recent outbreaks in Europe. It was noted that the sequence diversity amongst LSDV strains from Africa was higher than diversity from Eurasia.

Conclusion: The LSDV strains circulating in Uganda were closely related with sequences from neighboring African countries and from Eurasia. Comparison of the GPCR gene showed that outbreak strains differed from vaccine strains. This information is necessary to understand LSDV molecular epidemiology and to contribute knowledge towards the development of control strategies by the Government of Uganda.
\end{abstract}

Keywords: Molecular detection, GPCR, Phylogenetic analysis, Lumpy skin disease, Uganda

\section{Background}

Lumpy skin disease virus (LSDV) belongs to the genus Capripoxvirus, subfamily Chordopoxvirinae and family Poxviridae [1]. Lumpy skin disease (LSD) is characterised by enlarged superficial lymph nodes, fever and growth of firm skin nodules that become open wounds leading to secondary bacterial infections, sometimes resulting in death of

\footnotetext{
* Correspondence: fmwiine@gmail.com; mwiine@covab.mak.ac.ug ${ }^{1}$ College of Veterinary Medicine, Animal resources and Biosecurity, Makerere University, P.O.BOX 7062 Kampala, Uganda

Full list of author information is available at the end of the article
}

clinically ill cattle [2, 3]. Internationally, LSD leads to financial losses due to trade restrictions applied to live cattle, sheep, goats and animal products from affected countries [4]. In Eastern Africa, economic loss is due to restrictions in animal movement, vaccination costs, and costs of treating secondary bacterial infections. The direct economic loss due to LSD is estimated at 141 USD per lactating head of cattle while the vaccination cost is 5 USD per cow [5].

In different epizootic circumstances, LSD morbidity and mortality fluctuate between 3 to $85 \%$, and between 1 and $40 \%$ respectively, based on whether the outbreak is

(c) The Author(s). 2020 Open Access This article is distributed under the terms of the Creative Commons Attribution 4.0 International License (http://creativecommons.org/licenses/by/4.0/), which permits unrestricted use, distribution, and 
in an endemic or non-endemic region [6, 7]. These broad ranges of morbidity and mortality are likely owing to genetic differences in livestock breeds resulting in varying susceptibility to disease, variable virulence of viral isolates and varying effectiveness of transmission of insect vectors involved in LSDV transmission $[2,4,8]$.

In 1929, LSD was first recorded in sub-Saharan Africa [9], spreading to most areas of Africa by the late 1980s $[10,11]$. The disease then spread to Middle East nations and more recently spread to Southeast Europe from the Middle East [12], affecting member states of the European Union $[13,14]$ and several other Balkan countries $[15,16]$. In Uganda, LSD is considered endemic and numerous outbreaks occur each year and some of these outbreaks may not be reported to government veterinary authorities. LSD in Uganda is controlled through quarantine restrictions and vaccination with live attenuated vaccines. Vaccination against LSD in Uganda is a responsibility of the livestock farmers rather than government. This may lead to misuse or abuse of vaccines bringing about co-infection and recombination of vaccine strains with virulent strains [17], resulting in virulent reversal of vaccine strains, which may lead to more outbreaks.

Effective control or eradication of LSD in endemic and non-endemic regions needs fast and precise diagnostic techniques to make a presumptive diagnosis. Typically, LSD laboratory testing involves virus isolation (VI), fluorescent antibody testing (FAT), electron microscopy, polymerase chain reaction (PCR), virus neutralization tests (VNT) and enzyme-linked immunosorbent assays (ELISA) [18]. Despite most of these tests being reliable and sensitive, they may not be easily accessible in some developing nations, though PCR has become cheaper and therefore more accessible. In addition, some of the serological tests have low specificity owing to cross-reactions between Parapoxvirus and Capripoxvirus [19]. Furthermore, these diagnostic tests require adequate financial, infrastructural, human resources and an adequate information system that are challenging to introduce under the current Ugandan setting. Therefore, control measures through vaccination and animal movement restrictions remain as the most practical options to control LSD in Uganda. However, LSD control through vaccination may be endangered by improper use of vaccines and by reports of partial protection of current LSD vaccines [20, 21]. Hence, the need for undertaking genetic characterization of LSDV during outbreaks to understand the genetic variation of field isolates. This genetic variation will give insights into the level of transboundary circulation of viruses, help identify disease hotspot areas and provide data which can be used to identify the origin of the LSDVs which caused outbreaks in Asia and South Eastern Europe.

Sensitive and specific molecular methods targeting p32, RPO30 and GPCR genes have been used to detect and characterise LSDV and other Capripoxviruses [22]. The Gprotein-coupled chemokine receptor (GPCR) gene is one of the variable genes within Capripoxviruses [23] and is an appropriate target for genetic distinction between Capripoxviruses [24]. The suitability of the GPCR gene for host range phylogenetic grouping was described by Le Goff et al 2005 [25] and has been used by various authors to characterise Capripoxviruses [21, 22, 26-29]. The GPCR gene encodes a protein related to the G-protein-coupled chemokine receptor subfamily. The protein has the main structural features of the superfamily of G-protein-coupled chemokine receptors, such as seven hydrophobic areas and cysteine residues in the first and second extracellular loops. Even though previous studies have explored the epidemiology of LSDV in Uganda [30, 31], there is no data on the molecular characterization of circulating LSDV viruses. These data are important for understanding molecular epidemiology and vaccine design for disease control. In this study, we applied molecular methods to confirm LSDV infections from six outbreaks which occurred in different districts of Uganda 2017-2018 and performed phylogenetic analysis of LSDV GPCR gene, amplified from cattle samples obtained during these outbreaks.

\section{Results}

\section{Field observations and confirmation of cases}

Six suspected LSD outbreaks were investigated in five districts of Uganda in 2017 and 2018. A single outbreak was investigated in 2017 in Mbarara district, while in 2018, five outbreaks were investigated; in Hoima (one outbreak), Kotido (two outbreaks), and Moroto (two outbreaks). In Moroto district the two outbreaks investigated occurred in three herds. Of these three herds, two herds were from the same village (Matheniko-Rupa) and were therefore considered one outbreak (Additional file 1). The common clinical signs observed in cattle suspected to have LSDV were fever, depression, enlarged superficial lymph nodes, loss of appetite, circumscribed skin nodules on different parts of the body, lacrimation, nasal discharges and decrease in body weight (Fig. 1), (Table 1), (Additional file 1). The six (6) different outbreaks affected eight (8) cattle herds. In the affected herds, twenty three (23) suspected cases were sampled. Out of the 23 suspected cases, 15 were confirmed positive by PCR (65.2\%). These confirmed cases were subjected to a second PCR targeting the GPCR gene (Additional file 2), sequenced and the sequences translated to amino acids to confirm presence of unique LSDV signature sequences (Fig. 2). One GPCR gene sequence from each of the eight outbreak herds was analysed in this study.

\section{Phylogenetic analysis of LSDV using the GPCR gene}

Phylogenetic analyses were performed to determine the phenetic relationship among Ugandan isolates and other Capripoxviruses whose sequences were obtained from 


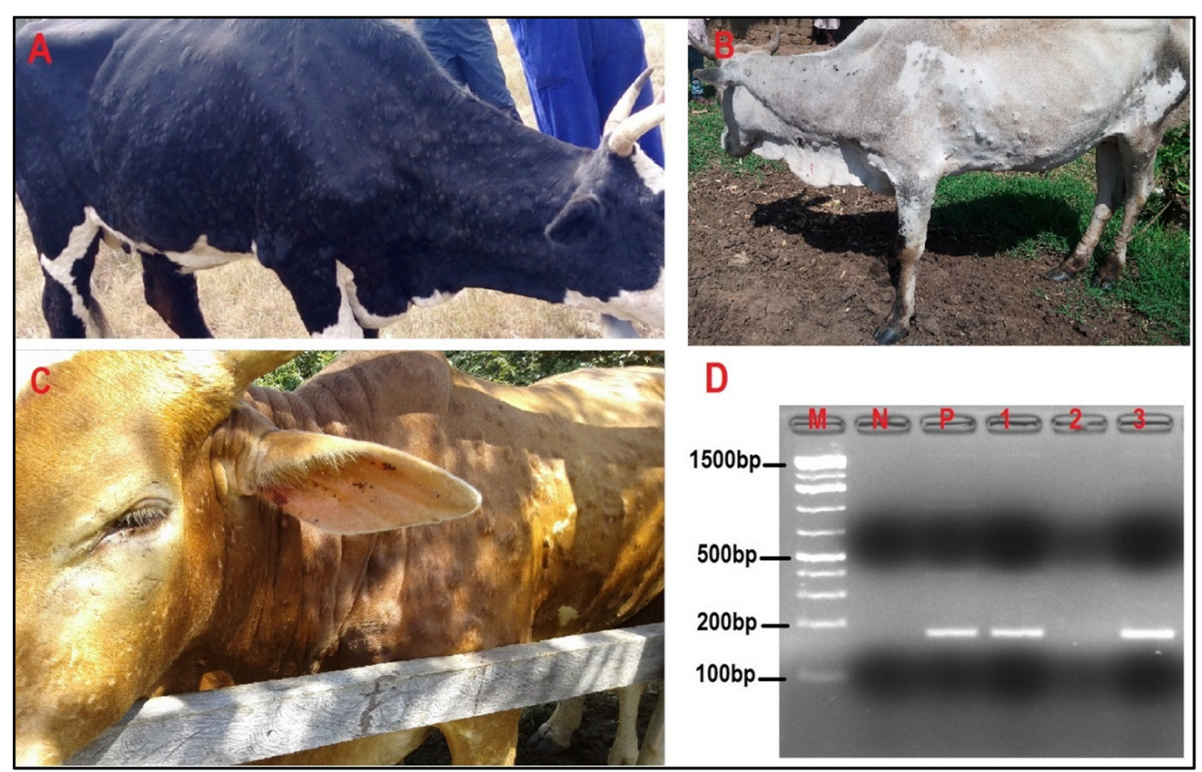

Fig. 1 Lumpy skin disease virus, observed clinical signs and molecular (PCR) confirmation results: Cattle showing characteristic LSDV clinical signs; nodular skin lesions covering the whole body; and lacrimal discharge (panel A shows a cow with nodular skin lesions covering the whole body, panel B shows skin nodules on the neck and fore body and panel $C$ shows skin nodules covering the whole body and lacrimal discharge). Panel D; PCR results showing a 192 bp fragment of the LSDV P32 gene, Lane M is a 100 bp molecular ladder (GeneDireX Inc., UK), lane N is a negative control, lane $\mathrm{P}$ a positive control. Lane 2 is a negative sample, while lanes 1 and 3 are samples positive for LSDV. All PCR products were run in 1.5\% agarose gel

GenBank (Table 2). Phylogenetic analysis clustered LSDV outbreak and vaccine strains into separate clades within the Capripoxvirus family. Sheeppox virus and goatpox viruses also clustered in separate clades (Fig. 3). The field LSDV isolates from Ugandan cattle were more closely related to other LSDV sequences from Africa (Kenya, Ethiopia, Egypt and Sudan) and from Europe (Greece and Russia). The Ugandan outbreak samples showed nucleotide sequence identities between 94.35 and $99.01 \%$ when compared to outbreak sequences from GenBank. When compared to vaccine strain sequences, nucleotide identities were $2-3 \%$ lower than when compared to outbreak sequences, and gave identities between 91.64 and $96 \%$. The diversity of sequences from Uganda is higher when compared amongst each other and did not all cluster with each other (Fig. 3).

\section{Comparison of outbreak samples with vaccine strains}

The analysis of the GPCR gene showed major sequence differences between the vaccine strain and the field isolates. A 12 bp nucleotide deletion (Fig. 4) was found in the GPCR gene for all outbreak isolates collected from cattle in Uganda while no such deletion was observed in the vaccine strains.

\section{Discussion}

This study presents the first results of molecular detection and phylogenetic analysis of lumpy skin disease virus from outbreaks in Uganda, which occurred between 2017 and
2018. In Uganda, LSDV is endemic and currently control of the disease is through quarantine restrictions and vaccination [7]. Vaccination is not done by the government which affects the coverage and quality of vaccines used. LSD vaccination is conducted by those farmers that can access and/or afford the cost of vaccines and delivery of vaccines into the animals. This limitation poses a danger of misuse or abuse of the use of vaccines which may result in reversion of vaccine strains into virulent strains, consequently being responsible for new outbreaks [17]. This study therefore presents insights into the current viruses responsible for outbreaks in the country and compares them to viruses from neighboring countries and with LSDV vaccine strains.

During the study, a conventional PCR using primers that target a $192 \mathrm{bp}$ region of the LSDV P32 gene was used to confirm presence of LSDV viral DNA from suspected clinical cases presenting with multiple skin nodules. Not all the samples obtained from suspected clinical cases tested positive by PCR, Fifteen (15) samples out of twenty three (23) tested positive. This is likely because only a blood sample was taken from some animals, and these blood samples tested negative. The reason for a negative result from a blood sample taken from a clinically sick animal could be that the virus is known to be present in blood for a short time 4-11 days, hence may have been missed [32]. This result is however in agreement with previous reports by Zeynalova et al 2016 [33], 
Table 1 Description of outbreaks, location of herd and descriptive data collected from the suspected cases of Lumpy skin disease investigated between 2017 and 2018

\begin{tabular}{|c|c|c|c|c|c|c|}
\hline $\begin{array}{l}\text { Date of } \\
\text { Investigation }\end{array}$ & Location & Setting & Species/breed & $\begin{array}{l}\text { Number of } \\
\text { Cattle sampled }\end{array}$ & Clinical signs observed & $\begin{array}{l}\text { Sample (s) } \\
\text { collected }\end{array}$ \\
\hline January 27, 2018 & Hoima & Farm & Cattle, Ankole & 2 & pyrexia, nodular skin lesions & Skin Biopsy, blood \\
\hline December 8, 2018 & Kotido & Nomadic herd & Cattle, Zebu & 2 & $\begin{array}{l}\text { pyrexia, nodular skin lesions, generalized } \\
\text { enlarged lymph nodes }\end{array}$ & Skin scab, blood \\
\hline December 8, 2018 & Kotido & Nomadic herd & Cattle, Zebu & 2 & $\begin{array}{l}\text { pyrexia, nodular skin lesions on the neck } \\
\text { and shoulder }\end{array}$ & Skin Scab, blood \\
\hline August 21, 2017 & Mbarara & Farm & Cattle, Friesian & 5 & $\begin{array}{l}\text { pyrexia, nodular skin lesions, ocular } \\
\text { discharges }\end{array}$ & Skin Biopsy, blood \\
\hline December 7, 2018 & Moroto & Nomadic herd & Cattle, Zebu & 4 & pyrexia, nodular skin lesions & Skin Biopsy, blood \\
\hline December 7, 2018 & Moroto & Nomadic herd & Cattle, Zebu & 3 & pyrexia, nodular skin lesions & Skin Biopsy, blood \\
\hline December 7, 2018 & Moroto & Nomadic herd & Cattle, Zebu & 3 & pyrexia, nodular skin lesions & Skin Biopsy, blood \\
\hline March 4, 2018 & Sembabule & Farm & $\begin{array}{l}\text { Cattle, Friesian } \\
\text { cross }\end{array}$ & 2 & pyrexia, nodular skin lesions & EDTA blood \\
\hline
\end{tabular}

who concluded that skin nodules are better samples for PCR detection of LSDV than blood samples.

The sequences obtained from the GPCR gene amplicons were translated into corresponding amino acid sequences and when checked for presence of unique signatures associated with LSDV as reported by Le Geoff et al 2009 [34], these translated GPCR amino acid sequences showed these unique LSDV signatures (A11, T12, T34, S99, and P199) therefore further confirming LSDV (Fig. 2). To the best of our knowledge this is the first published study reporting LSDV in Uganda using molecular methods. BLAST analysis revealed high sequence homology $94.35-99.01 \%$ between Ugandan LSDV sequences and sequences in GenBank. Phylogenetic analysis of GPCR gene sequences was able to group the Capripoxviruses into three distinct groups (LSDV, SPPV and GTPV). Phylogenetic analysis further showed that LSDVs from outbreaks in Uganda grouped with LSDV isolates from Kenya, Egypt, Sudan, Ethiopia, Turkey, Serbia, Russia, Kazakhstan and Greece (Fig. 3). These sequences were however most closely related to sequences from Kenya and Sudan when compared by nucleotide identity, therefore suggesting that the same
LSDVs are responsible for outbreaks across borders. This is highly likely because of the porous nature of the border between Kenya and Uganda. In the northeastern border of Uganda and Kenya, there are pastoral communities who move across the borders in search of pasture and water for their cattle therefore easily spreading diseases such as LSD. It is interesting to note that the diversity of the GPCR sequences from this study is higher than what has been previously observed, where most of the GPCR sequences in GenBank are almost identical. We however did not observe any trend in virus circulation amongst the different livestock production systems in Uganda. This is more likely due to the small number of LSDV sequences being compared in this study and comparison of only a single gene.

Comparison of GPCR gene sequences from this study with GPCR sequences from LSDV vaccine strains (obtained from GenBank) commonly used in the East African region revealed a 12 bp deletion between nucleotide position 94 and 105 in the outbreak sequences when compared to the LSDV vaccine strains. This finding is similar to reports by Gelaye et al 2015 [21] who reported similar deletions in the GPCR gene of virulent LSDVs. The

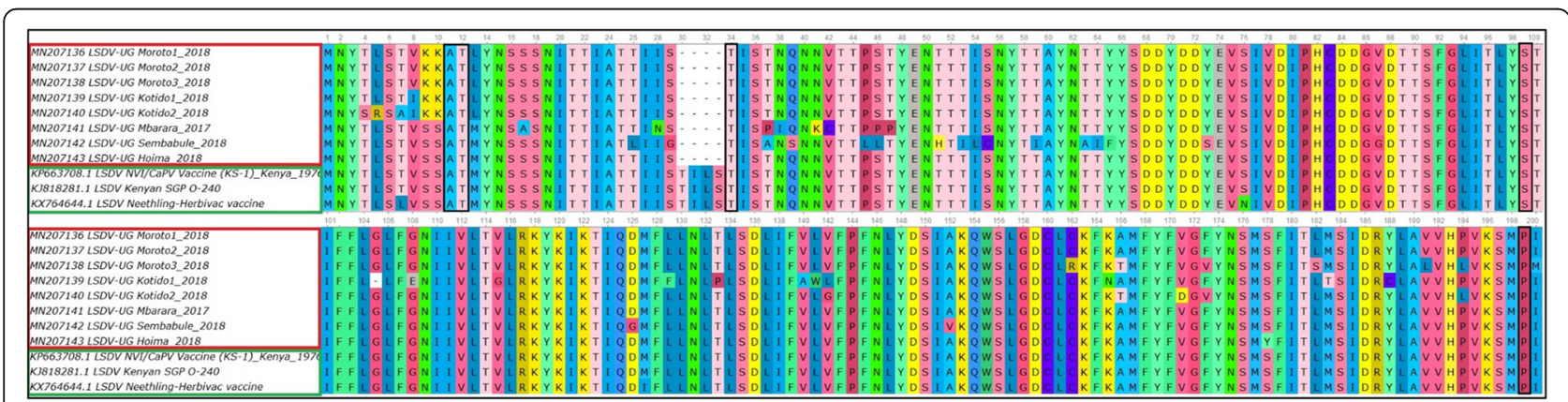

Fig. 2 Multiple sequence alignment of GPCR sequences from Ugandan isolates and LSDV vaccine strains, showing positions of LSDV signature amino acid sequences A11, T12, T34, S99 and P199. Locations of the signature sequences are marked in a black horizontal rectanglar shape 
Table 2 Details of selected Capripoxvirus sequences used for phylogenetic analysis based on G-protein-coupled chemokine receptor gene

\begin{tabular}{|c|c|c|c|c|c|}
\hline Isolate name & Sequence Length (bp) & Country of origin & Year of collection & Host species & GenBank accession no. \\
\hline LSDV & 1134 & Russia & 2015 & Bovine & MH893760.2 \\
\hline LSDV & 1134 & Kenya & 2010 & Bovine & MK302072.1 \\
\hline LSDV & 1134 & Ethiopia & 2011 & Bovine & MK302073.1 \\
\hline LSDV & 1134 & Serbia & 2016 & Bovine & KY702007.1 \\
\hline LSDV & 1134 & Burkina Faso & 2010 & Bovine & FJ869352.1 \\
\hline LSDV & 1038 & Turkey & 2014 & Bovine & KR024745.1 \\
\hline LSDV & 1134 & Kenya & 2014 & Bovine & KJ818281.1 \\
\hline LSDV & 1134 & Sudan & 2008 & Bovine & MK302082.1 \\
\hline LSDV & 1134 & South Africa & 2010 & Bovine & FJ869374.1 \\
\hline LSDV & 1134 & Greece & 2015 & Bovine & KY829023.3 \\
\hline LSDV & 1134 & Egypt & 2016 & Bovine & MG970345.1 \\
\hline LSDV & 507 & Egypt & 2018 & Bovine & MN271725.1 \\
\hline LSDV & 507 & Egypt & 2019 & Bovine & MN271733.1 \\
\hline LSDV & 1134 & Russia & 2019 & Bovine & MK452255.1 \\
\hline LSDV & 791 & Russia & 2016 & Bovine & MK765545.1 \\
\hline LSDV & 779 & Kazakhstan & 2016 & Bovine & MK765544.1 \\
\hline LSDV vaccine & 1146 & South Africa & 2016 & Bovine & KX764644.1 \\
\hline LSDV vaccine & 1146 & South Africa & 2016 & Bovine & KX764643.1 \\
\hline LSDV vaccine & 1146 & Croatia & 2016 & Bovine & MG972412.1 \\
\hline SPPV & 1056 & Turkey & 2017 & Sheep & MG731218.1 \\
\hline SPPV & 1125 & Turkey & 1998 & Sheep & FJ869389.1 \\
\hline SPPV & 1125 & Tunisia & 2001 & Sheep & FJ869347.1 \\
\hline GTPV & 1146 & Ethiopia & 2008 & Goat & KP663692.1 \\
\hline GTPV & 1146 & Kenya & 2014 & Goat & KJ818279.1 \\
\hline GTPV & 1146 & China & 2014 & Goat & KJ818280.1 \\
\hline GTPV & 1146 & Burkina Faso & 2010 & Goat & FJ869353.1 \\
\hline Deerpox & 723 & USA & 2018 & White-tailed deer & MF966153.1 \\
\hline
\end{tabular}

inferences for Uganda are that the current LSDVs causing outbreaks are genetically different from viruses in the Neethling vaccines used in the country. Nonetheless, in order to confirm these strain variations between the vaccine and the wild type virus, further diagnostic testing, along with the sequencing of several LSDV genes, must be done, as this study compared only a single gene. Our findings further indicate that despite the weak regulations governing vaccine acquisition in Uganda, the current outbreaks are most probably caused by wild type virus which differ genetically from vaccine strains. This also means that a differential diagnostic method can be developed based on this sequence difference between vaccine and wild type virus, and this can be used as a tool to monitor vaccination [35]. Vaccination is reported as the best way to control LSDV and it can be done with attenuated LSDV, sheeppox and goatpox viruses [36, 37]. It is however still necessary to evaluate the efficacy of the currently approved LSDV vaccines under field conditions in Uganda, before mass vaccination can be rolled out.

\section{Conclusions}

This is the first study on molecular detection and phylogenetic analysis of LSDV in Uganda, using the GPCR gene. These findings hint at genetically similar LSDV viruses circulating in the East African region, and this emphasizes the transboundary nature of LSDV. In addition, we note here that based on a single gene comparison, outbreak viruses differ from vaccine strain viruses. In order to fully understand the molecular epidemiology of LSDV in Uganda, further characterization is required using whole genome sequencing. 


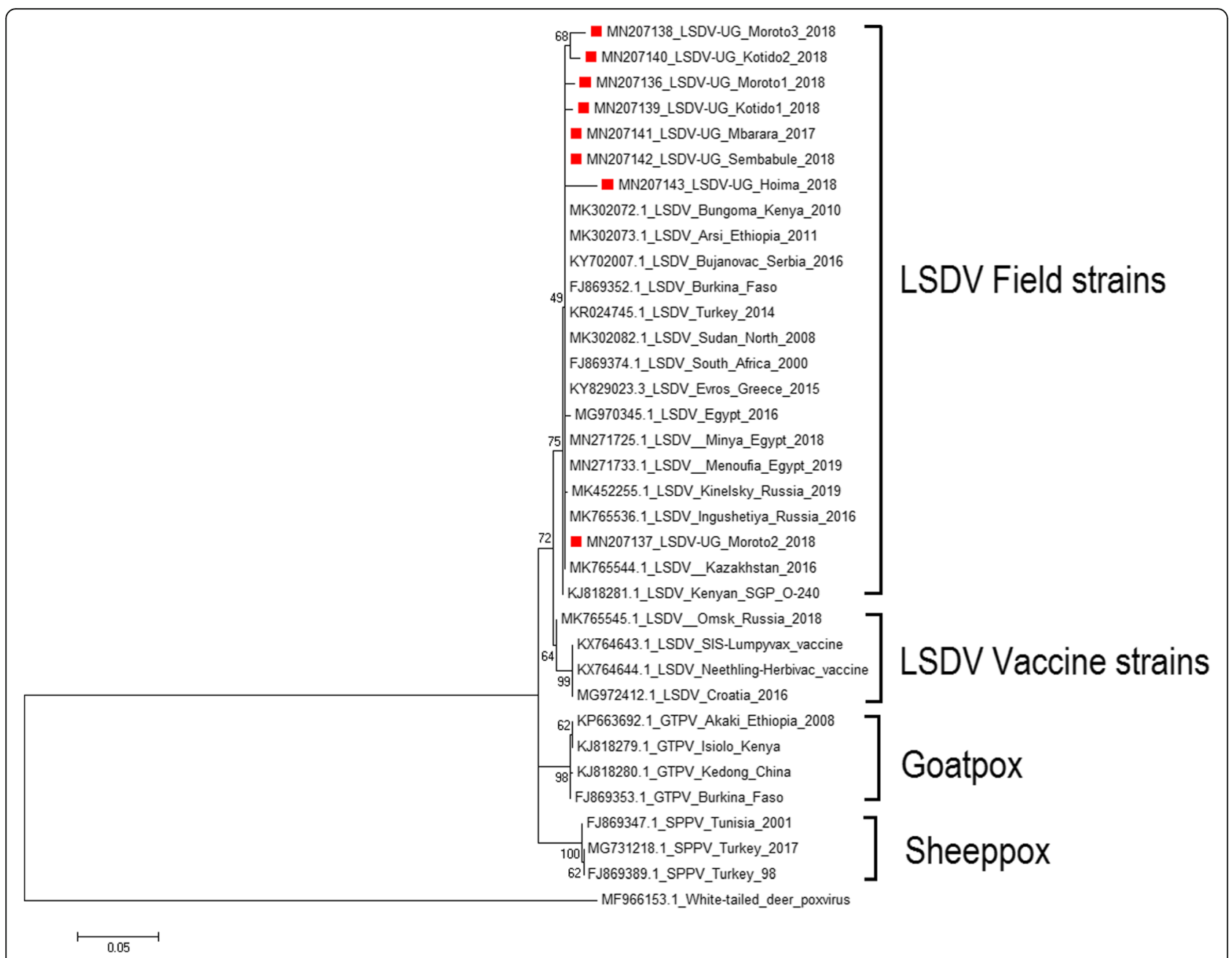

Fig. 3 Phylogenetic tree showing the relationship between LSDV GPCR gene sequences from Uganda, marked with red square, with other Capripoxvirus GPCR gene sequences from GenBank. A homologous gene sequence from Deerpox virus retrieved from GenBank was used as out-group to root the tree

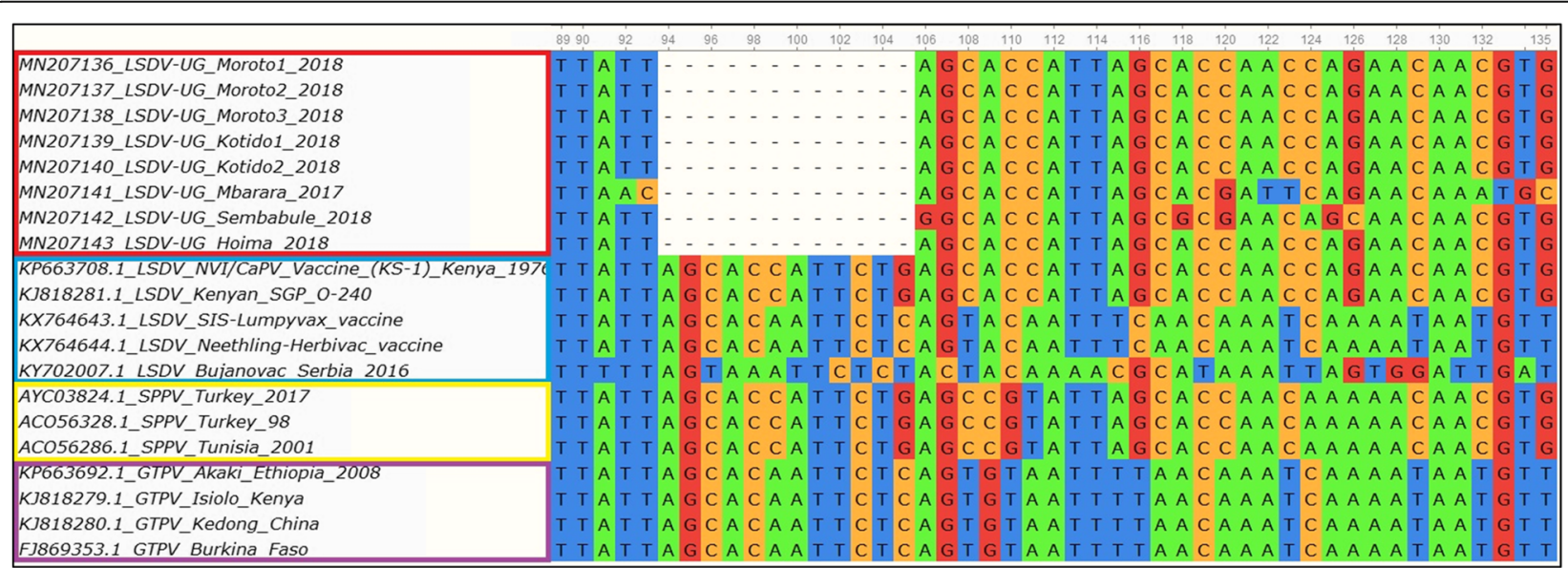

Fig. 4 Multiple sequence alignment of GPCR gene sequences of Ugandan LSDV field isolates, vaccine strains, Sheeppox and Goatpox virus. A 12 bp nucleotide (position 94 to 105) deletion unique to only LSDV from this study is shown. Sequences from Uganda are marked with a red rectangle, vaccine strains in blue, Sheeppox in yellow and Goatpox in purple 


\section{Methods}

\section{Study area, origin of samples and sample collection}

The study was undertaken in five districts of Moroto, Kotido, Mbarara, Sembabule and Hoima (Fig. 5). The study districts were located in North East (Moroto, Kotido), Central (Sembabule) and Western (Mbarara, Hoima) regions. Uganda is divided into 121 districts found in four major administrative regions: North, East, Central and West. Each region is primarily characterized by different livestock production systems: Northern region is characterised by agro-pastoral and pastoral system; Eastern region is mainly agro-pastoral; Central and west by agro-pastoral, semiintensive and ranching [38]. We sampled twenty-three cattle suspected to be affected by LSD from six field outbreaks

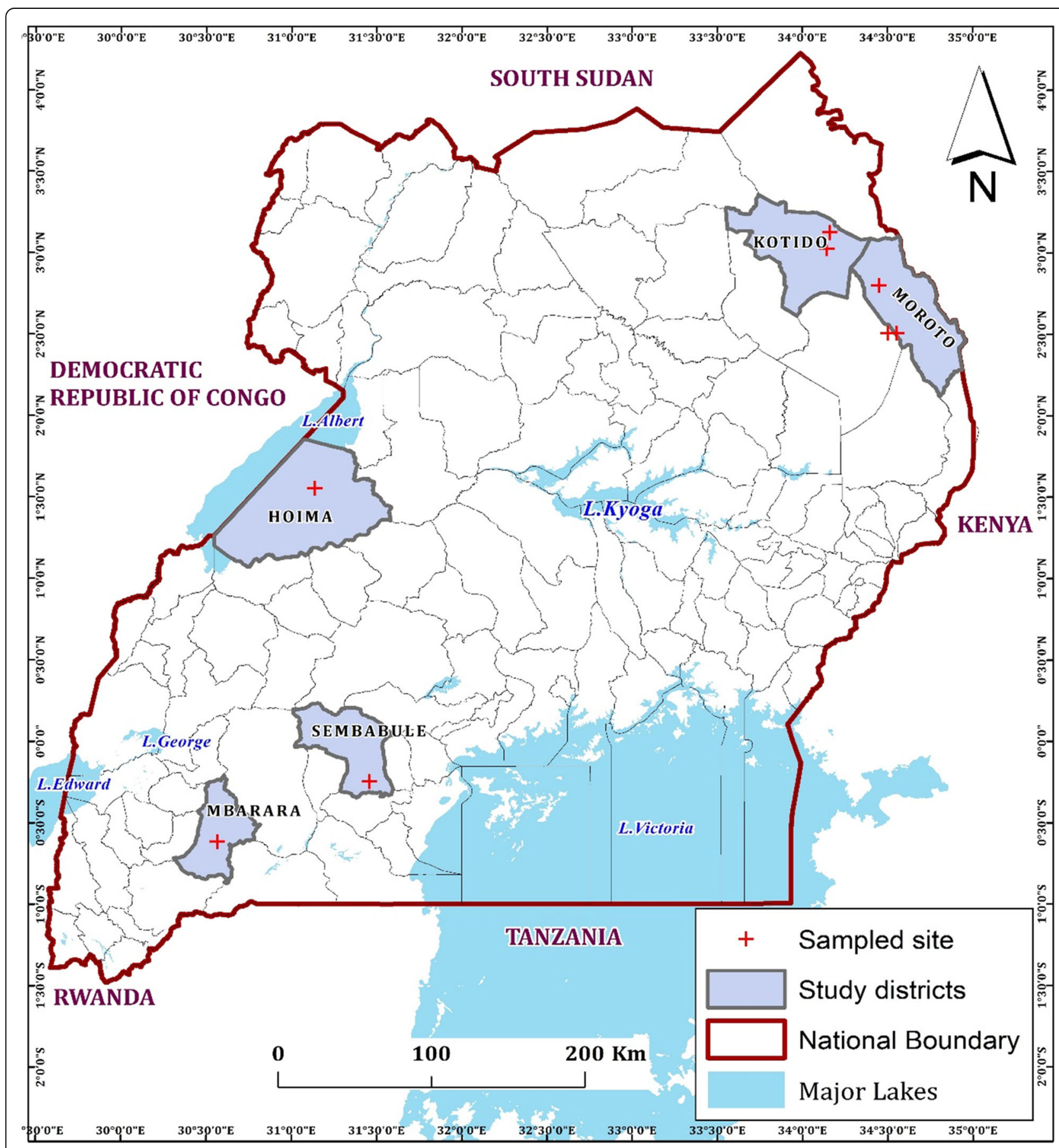

Fig. 5 Location of study area. Districts where outbreaks occurred are shown in grey with a bold dark boundary, coordinates of sampled sites are marked in a red cross. (The image depicted in Figure 5 is our own) 
in the 5 districts during the period from August 21, 2017 to December 8, 2018. The sampled animals were not previously vaccinated against LSDV. Samples of skin biopsies and scabs were collected in sterile cryovials containing 1 ml Minimum Essential Medium (MEM), Merck-Sigma, USA and whole blood in EDTA tubes. These samples were collected aseptically as described by the OIE [39]. In addition, information on clinical signs of the suspected LSD affected animals was recorded. Each sample was given a unique sample ID, placed in a cooler box with ice and transferred to the molecular biology laboratory, College of Veterinary Medicine Animal Resources and Biosecurity (COVAB) and stored at $-80{ }^{\circ} \mathrm{C}$ for further molecular analysis.

\section{DNA extraction and PCR confirmation of LSDV}

The samples (skin biopsies, scabs and whole blood) were thawed at room temperature. Skin biopsy and scab samples were cut with a sterile scalpel blade into small pieces weighing about $400 \mathrm{mg}$ and homogenized in $500 \mu \mathrm{l}$ of sterile 1X PBS solution, pH 7.4. Total DNA was extracted from tissue homogenates and $200 \mu \mathrm{l}$ blood aliquots using a DNeasy Blood and tissue kit (Qiagen, Germany) following manufacturer's instructions. PCR was then performed to confirm presence of LSDV specific nucleic acid by amplifying a 192 bp region in the p32 gene using a pair of primers; forward primer, 5' -TTTCCTGATTTTTCTTACTAT-3' and reverse primer, $5^{\prime}$-AAATTATATACG TAAATAAC$3^{\prime}$, and PCR conditions as described by Ireland and Binepal (1998) [40]. The PCR reaction was set up in a $50 \mu \mathrm{l}$ final volume containing $25 \mu \mathrm{l}$ of $2 \mathrm{X} \mathrm{MyTaq}{ }^{\mathrm{Tm}}$ Red mix (Bioline, United Kingdom), $1.5 \mu \mathrm{l}$ of each $10 \mu \mathrm{M}$ primer concentration, $19.5 \mu \mathrm{l}$ of PCR water, and $2.5 \mu \mathrm{l}$ of extracted DNA. The PCR was performed in a Bio-Rad S1000 ThermoCycler (Bio-Rad, United Kingdom). The PCR conditions had an initial denaturation step of $94{ }^{\circ} \mathrm{C}$ for $5 \mathrm{~min}$, followed by 34 cycles of denaturation at $94{ }^{\circ} \mathrm{C}$ for $1 \mathrm{~min}$, annealing at $50^{\circ} \mathrm{C}$ for $30 \mathrm{~s}$, extension at $72^{\circ} \mathrm{C}$ for $1 \mathrm{~min}$ and a final extension step of $72^{\circ} \mathrm{C}$ for $5 \mathrm{~min}$. The PCR products were viewed on a $1.5 \%$ Agarose gel to confirm LSDV positive samples, with a band size of $192 \mathrm{bp}$.

\section{PCR amplification of the GPCR gene}

A second PCR was carried out on all positive samples to amplify the GPCR gene for phylogenetic analysis. This was done using primers designed by Le Goff et al., 2009 [24], with the following sequences ( 5 ' - TTAAGTAAAG CATAACTCCAACAAAAATG- ${ }^{\prime}$ and $5^{\prime}$-TTTTTT TATTTTTTATCCAATGCTAATACT-3'), that were designed to amplify a fragment between nucleotide 6961-8119 in the LSDV genome [23]. An additional primer pair (5' -GATGAGTATTGATAGATACCTAGCTG TAGTT-3' and 5'-TGAGACAATCCA AACCACCAT- $\left.3^{\prime}\right)$ was positioned internally for sequencing [24]. The DNA amplification of the GPCR gene was performed in a $50 \mu \mathrm{l}$ volume in the presence of $25 \mu \mathrm{l}$ of $2 \mathrm{X} \mathrm{MyTaq}^{\text {max }}$ Red mix (Bioline, UK), $1.5 \mu \mathrm{l}$ of each $10 \mu \mathrm{M}$ primer concentration, $19.5 \mu \mathrm{l}$ of nuclease free water, and $2.5 \mu \mathrm{l}$ of DNA extract. The PCR amplification of the GPCR gene involved an initial denaturation at $96^{\circ} \mathrm{C}$ for $5 \mathrm{~min}$ followed by 35 cycles of final denaturation at $95^{\circ} \mathrm{C}$ for $30 \mathrm{~s}$, annealing at $50^{\circ} \mathrm{C}$ for the $30 \mathrm{~s}$, and extension at $72{ }^{\circ} \mathrm{C}$ for 30s as previously described. All PCR products were resolved on $1.5 \%$ agarose gel against HyperLadder ${ }^{\mathrm{m}}$ 100 bp DNA ladder (Bioline, United Kingdom) at $125 \mathrm{~V}$ in $1 \mathrm{X}$ Tris-Acetic acid-EDTA (TAE) buffer containing $0.5 \mu \mathrm{g} / \mathrm{ml}$ ethidium bromide for $35 \mathrm{~min}$. The gels were visualized using the ENDURO $^{\text {ma }}$ gel documentation system (LaboNet, USA).

\section{Nucleotide sequencing and analysis}

Following agarose gel electrophoresis on a 1.5\% agarose gel, amplification products of the expected size were identified against a molecular weight marker. DNA bands of correct size were excised and purified by gel purification (Qiagen, Germany), as specified by the manufacturer, and sent to Inqaba Biotec (South Africa) for Sanger sequencing. The sequences obtained were checked for quality and the ends of the sequences trimmed using BioEdit software (Ibis Biosciences, Carlsbad, CA, USA). The trimmed sequences were then checked for similarity with other LSDV GPCR sequences in GenBank using the National Center for Biotechnological Information's (NCBI) webbased Basic Local Alignment Search Tool (BLASTn). These nucleotide sequences were then further checked for LSDV-specific signatures by translating them to amino acid sequences followed by multiple sequence alignment using MUSCLE found at the EMBL-EBI web server. Phylogenetic analysis was done using Molecular Evolutionary Genetics Analysis (MEGA) version 6 (Pennsylvania, USA). Thirty four (34) Capripoxvirus and one Deerpox GPCR sequence (used to root tree) were selected from GenBank to be used for phylogenetic analysis. After BLAST, LSDV sequences were selected based on nucleotide similarity and origin of isolates, so as to have representative sequences from East Africa, the rest of Africa and Eurasia. We also selected sequences from LSDV vaccine strains, goatpox and sheeppox virus. A phylogenetic tree was constructed using the maximum likelihood method based on Tamura 3 parameter model, with 1000 bootstrap replications. The tree was drawn to scale, with branch lengths in the same units as those of the evolutionary distances used to infer the phylogenetic trees. All sequences were submitted to GenBank and can be found under the accession numbers MN207136-MN207143. 


\section{Supplementary information}

Supplementary information accompanies this paper at https://doi.org/10. 1186/s12917-020-02288-5.

Additional file 1. Table showing details of all samples taken from cattle showing clinical signs consistent with Lumpy skin disease

Additional file 2. PCR amplification of the LSDV GPCR gene. PCR results showing a $1150 \mathrm{bp}$ fragment of the LSDV GPCR gene. Lane $\mathrm{M}$ is a $50 \mathrm{bp}$ molecular ladder (Hyper Ladder, Bioline UK), Lane P is positive control (LSDV vaccine), Lane $\mathrm{N}$ is negative control, lanes $1-5$ are positive samples. PCR products were run in $1.5 \%$ agarose gel

\section{Abbreviations}

COVAB: College of Veterinary Medicine Animal Resources and Biosecurity LSD: Lumpy Skin Disease; LSDV: Lumpy Skin Disease Virus; MAAIF: Ministry of Agriculture Animal Industry and Fisheries

\section{Acknowledgements}

The authors would like to acknowledge the district veterinary and local government staff who helped us during field sample collection. We would also like to acknowledge the different cattle farmers who agreed to participate in this study.

\section{Authors' contributions}

SO contributed to the conception of the idea, laboratory analysis and data collection, drafting and writing of the manuscript. KWW contributed to conception of the idea, design, interpretation of results, and manuscript preparation. AM contributed to interpretation of results and writing the manuscript. JN contributed to laboratory analysis and writing of the manuscript. CN contributed to laboratory analysis and drafting of the manuscript. SGW contributed to laboratory analysis and drafting of the manuscript. ARAO contributed to drafting of the manuscript, FM contributed to drafting of the manuscript, NN contributed to drafting of the manuscript, DKA contributed to drafting of the manuscript, FNM contributed to conception of the idea, design and writing of the manuscript. All authors read and approved the manuscript.

\section{Funding}

This research was funded by the University of Minnesota Academic Health Center and DAAD Germany, and they had no role in the design and execution of the study as well as the decision to publish this manuscript.

\section{Availability of data and materials}

The datasets generated and/or analysed during the current study are available in the National Center for Biotechnology Information (NCBI) repository, under these GenBank accession numbers MN207136, MN207137 MN207138, MN207139, MN207140, MN207141, MN207142, and MN207143.

\section{Ethics approval and consent to participate}

The study was approved by the Institutional Animal Ethics Review Committee (SBLS/REC/13/016), Makerere University, Uganda. Verbal informed consent was obtained from farmers before they were interviewed and samples taken from their cattle. This was preferred over written informed consent because in some regions of Uganda like Karamoja, most of the farmers cannot write or read and do not have legally appointed representatives. Verbal informed consent was obtained through a native language speaker (interviewer) who explained to the cattle farmers the benefits and risks involved with participating in this study. This consent was documented by the interviewer in a verbal consent document. The verbal consent documentation as well as the main protocols leading to results presented in this manuscript were reviewed and approved by the Makerere University, College of Veterinary Medicine Animal Resources and Biosecurity, School of Biosecurity, Biotechnical and Laboratory Sciences (SBLS) Research and Ethics committee.

\section{Consent for publication}

Not applicable.

\section{Competing interests}

The authors of this paper do not have any financial or personal relationship with other people or organisations that could inappropriately influence or bias the content of the paper. The authors therefore declare that they have no competing interests in the publication of this paper.

\section{Author details}

${ }^{1}$ College of Veterinary Medicine, Animal resources and Biosecurity, Makerere University, P.O.BOX 7062 Kampala, Uganda. ${ }^{2}$ College of Veterinary Medicine, University of Minnesota, 1365 Gortner Avenue St. Paul, MN, Minneapolis, MN 55108, USA. ${ }^{3}$ Ministry of Agriculture Animal Industry \& Fisheries, Berkley Ln, Entebbe, Uganda.

\section{Received: 12 September 2019 Accepted: 14 February 2020}

\section{1.}

\section{References}

1. Fauquet C., Mayo M.A., Maniloff J. DU\& BLA. Virus Taxonomy: VIII Report of thelnternational Committee onTaxonomy ofViruses. Elsevier Acad. Press. San Diego, California, USA London, UK. 2005;.

2. Davies FG. Lumpy skin disease of cattle: a growing problem in Africa and the near east. World Anim Rev 1991;68:37-42. Available from: http://www. fao.org/ag/aGa/agap/frg/feedback/war/u4900b/u4900b0d.htm.

3. OIE. Lumpy Skin Disease. OIE Terr. Man. [Internet]. 2017. p. 56. Available from: https://www.bertelsmann-stiftung.de/fileadmin/files/BSt/Publikationen/ GrauePublikationen/MT_Globalization_Report_2018.pdf\%0Ahttp://eprints.Ise. ac.uk/43447/1/India_globalisation\%2C society and inequalities\%28lsero\%29. pdf\%0Ahttps://www.quora.com/What-is-the.

4. Tuppurainen ESM, Venter EH, Shisler JL, Gari G, Mekonnen GA, Juleff N, et al. Review: Capripoxvirus diseases: current status and opportunities for control. Transbound Emerg Dis. 2015;64:729-45.

5. Molla W, de Jong MCM, Gari G, Frankena K. Economic impact of lumpy skin disease and cost effectiveness of vaccination for the control of outbreaks in Ethiopia. Prev Vet Med. [internet]. Elsevier; 2017;147:100-107. Available from: http://linkinghub.elsevier.com/retrieve/pii/S0167587717303999.

6. Coetzer JAW. Lumpy skin disease. In: Coetzer, J.A.W. and R.C. Tustin (eds). 2nd ed. Infect. Dis. Livest. University Press Southern Africa, Oxford; 2004.

7. OIE Manual of Diagnostic Tests and Vaccines for Terrestrial Animals. Lumpy Skin Disease: Aetiology Epidemiology Diagnosis Prevention and Control References. OIE Dis. Inf. 2012

8. Babiuk S, Bowden TR, Parkyn G, Dalman B, Manning L, Neufeld J, et al. Quantification of lumpy skin disease virus following experimental infection in cattle. Transbound Emerg Dis. 2008;55:299-307.

9. MacDonald RA. Pseudo-urticaria of cattle. Government of Northern Rhodesia: Department of Animal Health. 1931

10. Ali AA, Esmat M, Attia H, Selim A, Abdel-Hamid YM. Clinical and pathological studies of lumpy skin disease in Egypt. Vet Rec. 1990;127:549-50.

11. Nawathe DR, Asagba M, Abegunde A, Ajayi S, Durkwa L. Some Observations on the Occurrence of Lumpy Skin Disease in Nigeria. Zbl Vet Med B. 1982;29:31-6.

12. Tuppurainen ESM, Oura CAL. Review: lumpy skin disease: an emerging threat to Europe, the Middle East and Asia. Transbound Emerg Dis. 2012;59:40-8.

13. Agianniotaki El, Tasioudi KE, Chaintoutis SC, Iliadou P, Mangana-Vougiouka O, Kirtzalidou A, et al. Lumpy skin disease outbreaks in Greece during 201516, implementation of emergency immunization and genetic differentiation between field isolates and vaccine virus strains. Vet Microbiol; 2017;201:7884. Available from: http://dx.doi.org/10.1016/j.vetmic.2016.12.037.

14. Alexandrov T, Tuppurainen E, Miteva A. Lumpy skin disease epidemics in Europe preventive and control measures for an effective control ASF vs LSD. 2017;

15. Mercier A, Arsevska E, Bournez L, Bronner A, Calavas D, Cauchard J, et al. Spread rate of lumpy skin disease in the Balkans, 2015-2016. Transbound Emerg Dis. 2018;65:240-3.

16. European Food Safety Authority (EFSA). Lumpy skin disease: Data collection and analysis [Internet]. EFSA J. 2017. Available from: http://doi.wiley.com/10. 2903/j.efsa.2017.4773.

17. Sprygin A, Babin Y, Pestova Y, Kononova S, Wallace DB, Van Schalkwyk A, et al. Analysis and insights into recombination signals in lumpy skin disease virus recovered in the field. PLoS One. 2018;13:1-19.

18. OIE. LUMPY SKIN DISEASE Fact Sheet. 2017;1-5. Available from: http://www. oie.int/wahis/public.php?page=home]. 
19. Tian H, Chen Y, Wu J, Shang Y, Liu X. Serodiagnosis of sheeppox and goatpox using an indirect ELISA based on synthetic peptide targeting for the major antigen P32. Virol J. 2010;7:2-5.

20. Ayelet $G$, Abate $Y$, Sisay $T$, Nigussie $H$, Gelaye $E$, Jemberie $S$, et al. Lumpy skin disease: Preliminary vaccine efficacy assessment and overview on outbreak impact in dairy cattle at Debre Zeit, central Ethiopia. Antiviral Res; 2013;98:261265. Available from: http://dx.doi.org/10.1016/j.antiviral.2013.02.008.

21. Gelaye E, Belay A, Ayelet G, Jenberie S, Yami M, Loitsch A, et al. Capripox disease in Ethiopia: Genetic differences between field isolates and vaccine strain, and implications for vaccination failure. Antiviral Res; 2015;1 19:28-35. Available from: http://dx.doi.org/10.1016/j.antiviral.2015.04.008.

22. Zhou T, Jia H, Chen G, He X, Fang Y, Wang $X$, et al. Phylogenetic analysis of Chinese sheeppox and goatpox virus isolates. Virol J. 2012;9:1-8.

23. Tulman ER, Afonso CL, Lu Z, Zsak L, Kutish GF, Rock DL. Genome of lumpy skin disease virus. J Virol. 2001:75:7122-30

24. Le Goff C, Lamien CE, Fakhfakh E, Chadeyras A, Aba-Adulugba E, Libeau G, et al. Capripoxvirus G-protein-coupled chemokine receptor: a host-range gene suitable for virus animal origin discrimination. J Gen Virol. 2009;90:1967-77.

25. Le Goff C, Fakhfakh E, Chadeyras A, Adulugba EA, Libeau G, Hammami S, et al. Host-Range Phylogenetic Grouping of Capripoxviruses. Appl. GeneBased Technol. Improv Anim Prod Heal Dev Ctries. 2005:727-33. https://doi. org/10.1007/1-4020-3312-5_58.

26. Rohaim MA. Role of Ixodid (hard) tick in the transmission of lumpy skin disease. 2017:

27. Salnikov N, Kolcov TUA, Morgunov SZY, Gogin VGA, Yurkov ITS. Identification and characterization of lumpy skin disease virus isolated from cattle in the Republic of North Ossetia-Alania in 2015. 2018;1-5.

28. Abdallah FM, Damaty HM El, Kotb GF. Sporadic cases of lumpy skin disease among cattle in Sharkia province, Egypt : Genetic characterization of lumpy skin disease virus isolates and pathological findings 2018;11:1150-8.

29. El-Tholoth M, El-Kenawy AA. G-protein-coupled chemokine receptor gene in lumpy skin disease virus isolates from cattle and water Buffalo (Bubalus bubalis) in Egypt. Transbound Emerg Dis. 2014;63(6):e288-e295.

30. Ochwo S, Vanderwaal K, Munsey A, Ndekezi C, Mwebe R, Rose A, et al. Spatial and temporal distribution of lumpy skin disease outbreaks in Uganda ( 2002-2016). BMC Vet Res. 2018;14:174.

31. Ochwo S, Vanderwaal K, Munsey A, Nkamwesiga J, Ndekezi C, Auma E, et al, Seroprevalence and risk factors for lumpy skin disease virus seropositivity in cattle in Uganda. BMC Vet Res. 2019;15:236.

32. Tuppurainen ESM, Venter EH, Coetzer JAW. The detection of lumpy skin disease virus in samples of experimentally infected cattle using different diagnostic techniques, Vol 72. Onderstepoort J Vet Res. 2005;72:153-64.

33. Zeynalova S, Asadov K, Guliyev F, Vatani M, Aliyev V. Epizootology and molecular diagnosis of lumpy skin disease among livestock in Azerbaijan. Front Microbiol. 2016;7:1-7.

34. Goff C Le, Lamien CE, Fakhfakh E, Aba-adulugba E, Tuppurainen E, Wallace $\mathrm{DB}$, et al. Capripoxvirus G-protein-coupled chemokine receptor : a hostrange gene suitable for virus animal origin discrimination 2019;1967-77.

35. Agianniotaki El, Chaintoutis SC, Haegeman A, Tasioudi KE, Leeuw I De, Katsoulos P, et al. Development and validation of a TagMan probe-based real-time PCR method for the di ff erentiation of wild type lumpy skin disease virus from vaccine virus strains. J Virol Methods; 2017;249:48-57. Available from: http://dx.doi.org/10.1016/j.jviromet.2017.08.011.

36. European Food Safety Authority. Lumpy skin disease: vaccination is most effective control method [Internet]. EFSA. 2016 . p. 1. Available from: https:// www.efsa.europa.eu/en/press/news/160809[cited 72019 May].

37. Klement E, Broglia A, Antoniou SE, Tsiamadis V, Plevraki E, Petrović T, et al. Neethling vaccine proved highly effective in controlling lumpy skin disease epidemics in the Balkans. Prev. Vet. Med. 2018;

38. FAO and USAID. ASL2050 Livestock production systems spotlight - Uganda [Internet]. 2017. Available from: http://www.fao.org/ag/againfo/ programmes/en/ASL2050.html 1.

39. Office International des Epizooties (OIE). Chapter 3.4.12. Lumpy skin disease. OIE Terr. Man. 2018. 2018. p. 1158-71.

40. Ireland DC, Binepal YS. Improved detection of capripoxvirus in biopsy samples by PCR. J Virol Methods. 1998;74:1-7.

\section{Publisher's Note}

Springer Nature remains neutral with regard to jurisdictional claims in published maps and institutional affiliations.

\section{Ready to submit your research? Choose BMC and benefit from:}

- fast, convenient online submission

- thorough peer review by experienced researchers in your field

- rapid publication on acceptance

- support for research data, including large and complex data types

- gold Open Access which fosters wider collaboration and increased citations

- maximum visibility for your research: over $100 \mathrm{M}$ website views per year

At BMC, research is always in progress.

Learn more biomedcentral.com/submissions 